\title{
Sensitivity Comparison of Different Methods Used for RNA Extraction with Increasing Capacity for the Detection of COVID-19
}

\author{
Amit Kumar ${ }^{1}$, Poonam Dhull $^{2}$, Manisha $^{3}$, Prerna Aggarwal $^{4}$ \\ ${ }^{1-4}$ Viral Research \& Diagnostic Lab (VRDL), Kalpana Chawla Govt. Medical College and Hospital, Karnal, \\ Haryana-132001.
}

Corresponding Author: Prerna Aggarwal

\begin{abstract}
The emergence of a novel corona virus was seen in the human population since December 2019. The Covid-19 is posing a major burden on society. Severe Acute Respiratory Syndrome Corona Virus 2 (SARS-CoV-2) has since spread across the globe. Thus, early and correct diagnosis is very crucial to reduce its spread. So, most sensitive and specific method available to diagnose the Covid-19 is real-time reverse transcriptase PCR (qRT-PCR). A better qRTPCR result depends on the quality of the extracted RNA.

Recently, many commercial kits have become available for extraction of RNA from specimens. The goal of this study was to compare robustness or clinical performance of manual kits available to us (i) MDI Viral RNA Extraction Mini-prep Kit and 2 automated extraction systems such as (i) MagNA Pure 24 Roche (ii) Nextactor NX-48 Genolution. We used 48 pre-examined nasopharyngeal and oropharyngeal swab samples with low, medium and high cycle threshold $(\mathrm{Ct})$ values for this study and extraction was done in pooling of 1:5, $1: 6,1: 7,1: 8,1: 9,1: 10$.

Through this work, we conclude that MagNA Pure 24 Roche and MDI Viral RNA Extraction Mini-prep kit showed better result as compared to Nextactor NX-48 Genolution.
\end{abstract}

Keywords:- SARS-CoV-2, qRT-PCR, Extraction, Diagnosis.

\section{INTRODUCTION}

In 1960s, first human corona virus was identified and it showed characteristic feature like flu that were responsible for respiratory tract infection. In 2001 according to Canadian study report, about 500 patients were identified with Flu like symptoms out of which 17-18 were confirmed through polymerase chain reaction and found infected with corona virus ${ }^{(1,2)}$. In Dec. 2019 Corona virus was notified again and isolated from the pneumonia patients of Wuhan city in China. It has emerged as biggest pandemic across the world in 2020 and named as Covid-19 disease by World Health Organization ${ }^{(3,4)}$. It is a positive sense single stranded RNA virus.

It is spherical, pleomorphic, with glycoprotein envelope and has four subtypes such as alpha, beta, gamma, delta and many serotype that affect humans and other animals such as birds, dogs, cats, pigs $(5,6,7,8)$. New corona virus belongs to coronaviridae family, it has generated health emergency all over the world ${ }^{(9,10)}$. Because of rapid spreading of SARS-COV-2 all over world it has prompted for fast diagnostic testing based on RT-qPCR following RNA extraction ${ }^{(11,12,13)}$. All qPCR methods require RNA extraction for diagnosis after the swab samples are collected from the oropharyngeal and nasopharyngeal route $(14,15,16,17)$. The diagnosis of COVID -19 in virology laboratory, involves commonly these steps - viral inactivation, lysis, extraction of viral RNA and qRT-PCR amplification. Because of rapid spreading of 
virus the demand of molecular testing has increased $(18,19,20)$. So, to cater to more number of samples efficiently in less time, pooling of samples is an alternative especially when positivity in community is low ${ }^{(21,22,23)}$. In our lab pooling in numbers from 5 to 10 were tried by various RNA extraction methods to validate the results.

\section{MATERIALS AND METHODS}

Sampling:- Total numbers of 48 ( 8 positive and 40 negative) pre-examined samples were used during this study and extraction was done in the pools of 1:5, 1:6, 1:7, 1:8, 1:9 and 1:10 each of these samples. The samples were selected with Cts varying from high to low ${ }^{(22-30)}$.

\section{RNA Extractions}

In this study we compared three RNA extraction methods, (A) Manual Extraction (Column based) MDI Viral RNA Extraction Mini-prep kit (B) automated systems such as MagNA Pure 24 Roche (C) Nextactor NX-48 Genolution. RNA extraction was done by the following procedures using different modes:-

\section{(A) Manual method by MDI Viral RNA Extraction Mini-prep Kit:-}

Pipetted $560 \mu 1$ of buffer VRLCarrier RNA solution into a $1.5 \mathrm{ml}$ microcentrifuge tube and added $200 \mu \mathrm{l}$ (for single) of sample in it. After vortex Incubated at room temperature for 5 to $10 \mathrm{~min}$. Added $700 \mu 1$ ethanol in mixture then vortex and transferred the solution in spin columns, centrifuged it at $10000 \mathrm{rpm}$ for $1 \mathrm{~min}$. and discarded the flow through. Then washed with $500 \mu \mathrm{l}$ of VW1, and centrifuged at $10000 \mathrm{rpm}$ for $1 \mathrm{~min}$. Second time washed with $400 \mu \mathrm{l}$ VW2 for $2 \mathrm{~min}$ at $10000 \mathrm{rpm}$ for 1 min. Placed spin column in RNase free $1.5 \mathrm{ml}$ micro-centrifuge tube and added $40 \mu 1$ of buffer VE directly on the centre of column membrane. Left it for 4 to $5 \mathrm{~min}$ then spin at same speed for $1 \mathrm{~min}$ and stored eluted RNA at $-20^{\circ} \mathrm{C}$ till further use.

\section{(B) Automated method (I) by Nextractor NX-48 Genolution:-}

NX-48s viral NA kit contains four preloaded deep well plates (24 well each) with strips. Sample volume of $200 \mu 1$ required for each well as per the protocol provided by the company. The volume used for pools as 1:5, 1:6, 1:7, 1:8, 1:9 and 1:10 shown below in the table 1 . It works on the principle of using magnetic beads and extraction procedure followed the steps such as- (i) beads capturing (ii) lysis (iii) binding (iv) washing (v) evaporation and (vi) elution which took about 27 mins. Eluted RNA collected in RNase free micro-centrifuge tube and stored at $-20^{\circ} \mathrm{C}$ till further use.

\section{(C) Automated method (II) by MagNA Pure 24 Roche:-}

We used external lysis protocol for the extraction with Magna Pure 24 Total isolation kit and used all the accessories and reagents provided by the Roche Diagnostics. We standardized this protocol by making some changes in the volume of reagents and samples as shown below in the table 1. It took about 1 hour $20 \mathrm{~min}$ in the completion of extraction by following steps as lysis, binding, washing and elution. Eluted RNA stored it at $-20^{\circ} \mathrm{C}$ till further use. For all above methods protocol provided by the company was properly followed. Sample volume used for each pool ratio is given below in table 1 .

Table 1

\begin{tabular}{|l|l|l|l|l|l|l|l|}
\hline S.NO & Sample Id. & \multicolumn{6}{|l|}{ Pools Ratio with volume ( $\boldsymbol{\mu l})$ for single sample by MDI Viral RNA Extraction Mini-prep kit } \\
\hline & & $\mathbf{1 : 5}$ & $\mathbf{1 : 6}$ & $\mathbf{1 : 7}$ & $\mathbf{1 : 8}$ & $\mathbf{1 : 9}$ & $\mathbf{1 : 1 0}$ \\
\hline 1 & R 1512 & 40 & 33 & 28 & 25 & 22 & 20 \\
\hline 2 & R 1420 & 40 & 33 & 28 & 25 & 22 & 20 \\
\hline 3 & R1419 & 40 & 33 & 28 & 25 & 22 & 20 \\
\hline 4 & R1165 & 40 & 33 & 28 & 25 & 22 & 20 \\
\hline 5 & R1373 & 40 & 33 & 28 & 25 & 22 & 20 \\
\hline 6 & R1423 & 40 & 33 & 28 & 25 & 22 & 20 \\
\hline 7 & R1345 & 40 & 33 & 28 & 25 & 22 & 20 \\
\hline 8 & R 1371 & 40 & 33 & 28 & 25 & 22 & 20 \\
\hline
\end{tabular}


Amit Kumar et.al. Sensitivity Comparison of different methods used for RNA extraction with increasing capacity for the detection of COVID-19.

\begin{tabular}{|c|c|c|c|c|c|c|c|}
\hline \multicolumn{8}{|c|}{ Table 1 Continued... } \\
\hline & & \multicolumn{6}{|c|}{ Pools Ratio with volume $(\mu \mathrm{l})$ for single sample by Nextactor NX-48 Genolution Machine } \\
\hline & & $1: 5$ & $1: 6$ & $1: 7$ & $1: 8$ & $1: 9$ & $1: 10$ \\
\hline 1 & R 1512 & 40 & 33 & 28 & 25 & 22 & 20 \\
\hline 2 & R 1420 & 40 & 33 & 28 & 25 & 22 & 20 \\
\hline 3 & R1419 & 40 & 33 & 28 & 25 & 22 & 20 \\
\hline 4 & R1165 & 40 & 33 & 28 & 25 & 22 & 20 \\
\hline 5 & R1373 & 40 & 33 & 28 & 25 & 22 & 20 \\
\hline 6 & R1423 & 40 & 33 & 28 & 25 & 22 & 20 \\
\hline 7 & R1345 & 40 & 33 & 28 & 25 & 22 & 20 \\
\hline \multirow[t]{3}{*}{8} & R 1371 & 40 & 33 & 28 & 25 & 22 & 20 \\
\hline & & \multicolumn{6}{|c|}{ Pools Ratio with volume $(\mu 1)$ for single sample by MagNA Pure 24 Roche Machine } \\
\hline & & $1: 5$ & $1: 6$ & $1: 7$ & $1: 8$ & $1: 9$ & $1: 10$ \\
\hline 1 & R 1512 & 125 & 104.1 & 89.2 & 78.1 & 69.4 & 62.5 \\
\hline 2 & R 1420 & 125 & 104.1 & 89.2 & 78.1 & 69.4 & 62.5 \\
\hline 3 & R 1419 & 125 & 104.1 & 89.2 & 78.1 & 69.4 & 62.5 \\
\hline 4 & R 1165 & 125 & 104.1 & 89.2 & 78.1 & 69.4 & 62.5 \\
\hline 5 & R 1373 & 125 & 104.1 & 89.2 & 78.1 & 69.4 & 62.5 \\
\hline 6 & R 1423 & 125 & 104.1 & 89.2 & 78.1 & 69.4 & 62.5 \\
\hline 7 & R 1345 & 125 & 104.1 & 89.2 & 78.1 & 69.4 & 62.5 \\
\hline 8 & R 1371 & 125 & 104.1 & 89.2 & 78.1 & 69.4 & 62.5 \\
\hline
\end{tabular}

\section{PCR Amplification}

Amplification has been done by using COVIDsure Multiplex Realtime RTPCR Kit (LABSYSTEMS Diagnostics) with Roche LightCycler 480. SARS-CoV-2 specific primers and fluorescence labeled hydrolysis probes were used in this study according to the instructions of the kit. The specific primers are labeled with FAM specific to Orf1ab and HEX specific to E gene of SARS-CoV genome. The ROX specific dye was labeled to RPP30 human gene and serves as an internal control. Reaction mixture was prepared and used 15 $\mu 1 /$ reaction as per instructions. $5 \mu 1$ of $\mathrm{RNA} /$ reaction was used as template.
Negative and positive controls were also run in every PCR plate. PCR plate was rotated in mini-spin at 2500 RPM for 20 secs. The parameters for PCR cycling included reverse transcription ( 1 cycle) at $46^{\circ} \mathrm{C}$ for 15 min, initial activation ( 1 cycle) at $95^{\circ} \mathrm{C}$ for 2 mins. Amplification cycles as Annealing, Extension and signal acquisition run for 40 cycles at $58^{0} \mathrm{C}$ for 30 secs.

\section{RESULT}

There was no false positive and negative amplification observed during this study. Results were analyzed under the following conditions:-

\begin{tabular}{|c|c|c|c|c|}
\hline Sample & FAM (Orf1ab ) & HEX (E gene ) & ROX (RPP30 ) & Interpretation \\
\hline Test sample & $\mathrm{Ct} \leq 36$ & $\mathrm{Ct} \leq 36$ & $\mathrm{Ct} \leq 36$ & Viral RNA detected \\
\hline Test sample & $\mathrm{Ct} \leq 36$ & No amplification & $\mathrm{Ct} \leq 36$ & Viral RNA detected \\
\hline Test sample & No amplification & $\mathrm{Ct} \leq 36$ & $\mathrm{Ct} \leq 36$ & Presumptive positive (retested) \\
\hline Test sample & No amplification & No amplification & $\mathrm{Ct} \leq 36$ & Viral RNA not detected \\
\hline Test sample & No amplification & No amplification & No amplification & Invalid result, re-perform RNA extraction \\
\hline
\end{tabular}

Through this interpretation all three RNA extraction methodologies were checked. $\mathrm{Ct}$ value of the test samples was used earlier by RT- PCR was taken as control value. Results were shown as given table below:-

Table 3.

\begin{tabular}{|l|l|l|l|l|l|l|l|l|}
\hline S No. & \multicolumn{2}{|c|}{ Sample Id } & \multicolumn{6}{|c|}{ Ct value of pools by MDI Viral RNA Extraction Mini-prep Kit } \\
\hline & & Control value & $\mathbf{1 : 5}$ & $\mathbf{1 : 6}$ & $\mathbf{1 : 7}$ & $\mathbf{1 : 8}$ & $\mathbf{1 : 9}$ & $\mathbf{1 : 1 0}$ \\
\hline 1 & R 1512 & 29 & 29.5 & 29.6 & 29.7 & 30.0 & 30.1 & 30.2 \\
\hline 2 & R 1420 & 30 & 30.8 & 30.9 & 31.0 & 31.5 & 31.6 & 31.6 \\
\hline 3 & R 1419 & 30 & 30.7 & 30.8 & 31.2 & 31.3 & 31.4 & 31.4 \\
\hline 4 & R 1165 & 24 & 23.9 & 24.1 & 24.4 & 24.7 & 25.1 & 25.7 \\
\hline 5 & R 1373 & 24 & 24.8 & 26.4 & 26.5 & 27.1 & 27.2 & 27.2 \\
\hline 6 & R 1423 & 28 & 29.0 & 29.1 & 29.2 & 29.6 & 30.1 & 30.2 \\
\hline 7 & R 1345 & 22 & 22.1 & 22.5 & 23.6 & 23.7 & 23.8 & 23.9 \\
\hline 8 & R 1371 & 21 & 20.8 & 21.0 & 21.4 & 21.5 & 21.5 & 22.6 \\
\hline
\end{tabular}


Amit Kumar et.al. Sensitivity Comparison of different methods used for RNA extraction with increasing capacity for the detection of COVID-19.

\begin{tabular}{|c|c|c|c|c|c|c|c|c|}
\hline \multicolumn{9}{|c|}{ Table 3 Continued... } \\
\hline & & & \multicolumn{6}{|c|}{ Ct value of pools by Nextractor NX-48 Genolution } \\
\hline & & Control value & $1: 5$ & $1: 6$ & $1: 7$ & $1: 8$ & $1: 9$ & $1: 10$ \\
\hline 1 & R 1512 & 29 & 35 & 35 & 35 & 32 & 32 & 35 \\
\hline 2 & R 1420 & 30 & 35 & 35 & 35 & 32 & 31 & 35 \\
\hline 3 & R1419 & 30 & 34 & 36.4 & 35 & 32 & 31 & 31 \\
\hline 4 & R1165 & 24 & 28 & 30 & 30 & 28 & 28 & 26 \\
\hline 5 & R1373 & 24 & 27 & 29 & 29 & 27 & 27 & 29 \\
\hline 6 & R1423 & 28 & 34 & 34 & 32 & 29 & 36.6 & 36.7 \\
\hline 7 & R1345 & 22 & 26 & 26 & 28 & 25 & 24 & 28 \\
\hline \multirow[t]{3}{*}{8} & R 1371 & 21 & 26 & 26 & 27 & 21 & 22 & 26 \\
\hline & & & \multicolumn{6}{|c|}{ Ct value of pools by MagNA Pure 24 Roche } \\
\hline & & Control value & $1: 5$ & $1: 6$ & $1: 7$ & $1: 8$ & $1: 9$ & $1: 10$ \\
\hline 1 & R 1512 & 29 & 28.7 & 28.9 & 29.9 & 30.8 & 30.9 & 31.4 \\
\hline 2 & R 1420 & 30 & 28.5 & 28.8 & 30.1 & 30.3 & 30.3 & 31.0 \\
\hline 3 & R 1419 & 30 & 28.3 & 28.8 & 28.8 & 29.4 & 29.7 & 30.7 \\
\hline 4 & R 1165 & 24 & 26.0 & 26.7 & 26.8 & 28.3 & 29.3 & 29.3 \\
\hline 5 & R 1373 & 24 & 25.3 & 25.4 & 25.4 & 25.5 & 25.9 & 27.7 \\
\hline 6 & R 1423 & 28 & 28.2 & 30.1 & 30.2 & 30.2 & 30.2 & 31.0 \\
\hline 7 & R 1345 & 22 & 23.1 & 23.2 & 23.2 & 23.9 & 24.0 & 24.0 \\
\hline 8 & R 1371 & 21 & 22.5 & 22.5 & 22.6 & 22.7 & 22.8 & 23.8 \\
\hline
\end{tabular}

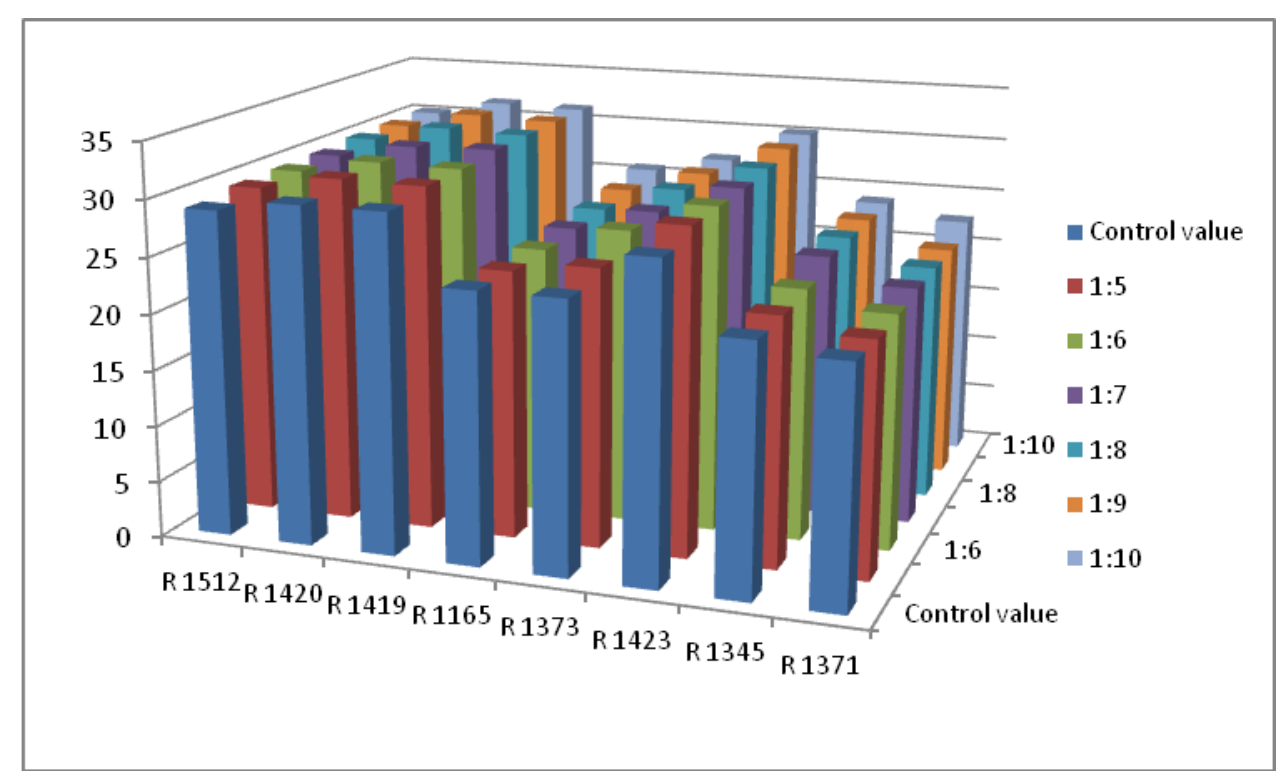

Fig 1 Vertical axis represents Ct values (pools ratios) and horizontal axis represents sample id. (MDI Viral RNA Extraction Miniprep Kit)

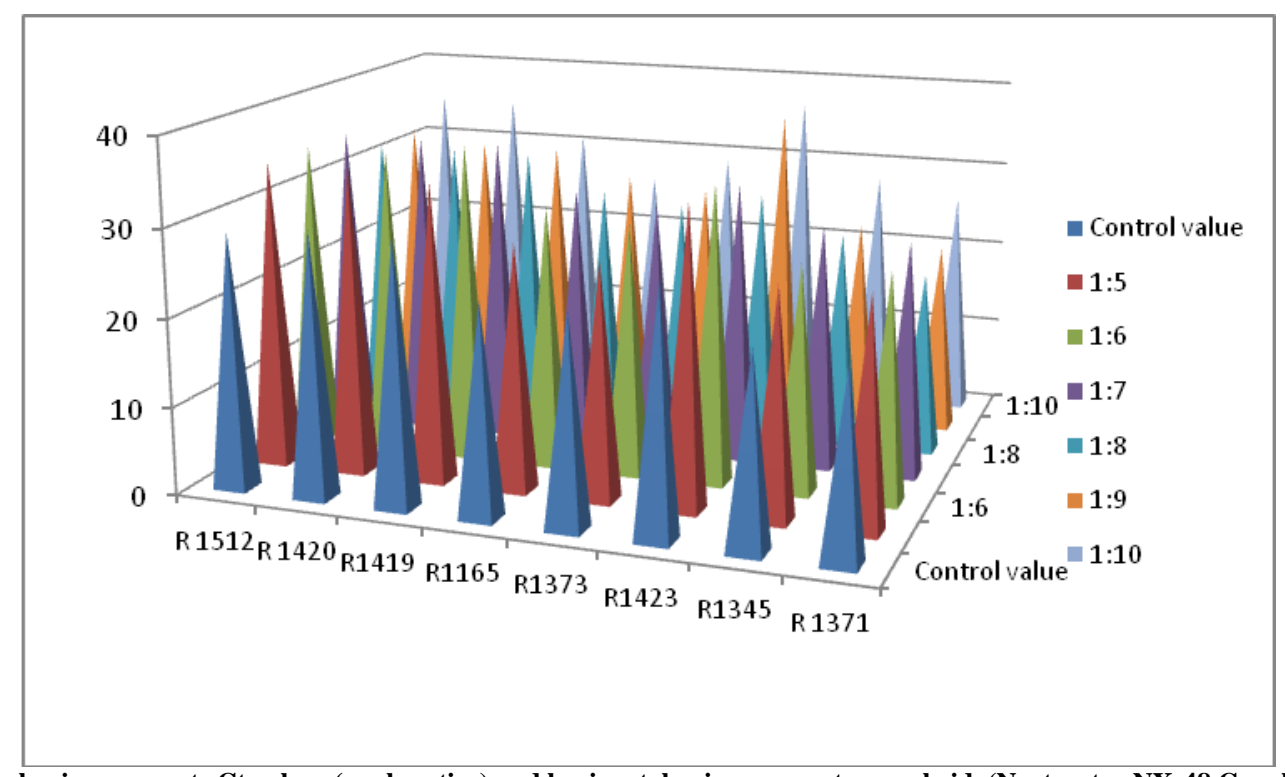

Fig2. Vertical axis represents $\mathrm{Ct}$ values (pools ratios) and horizontal axis represents sample id. (Nextractor NX-48 Genolution) 


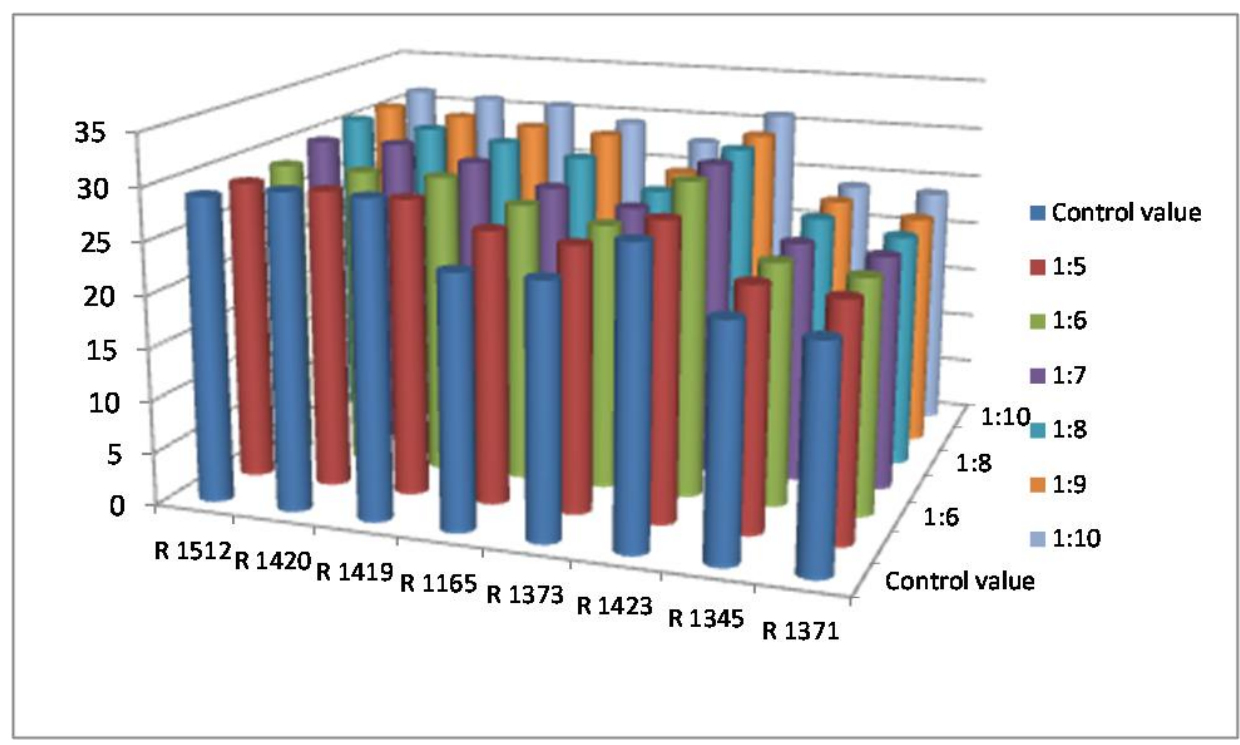

Fig3. Vertical axis represents Ct values (pools ratios) and horizontal axis represents sample id. (MagNA Pure 24 Roche)

Same samples were used during the manual and automated extraction. Sample R 1512, R 1420, R 1419 and R 1371 showed the better results in case of MagNA Pure 24 Roche and MDI Viral RNA Extraction Mini-prep Kit. All other samples also showed good results and extraction efficiency and sensitivity was good in these two extraction methodologies. Extraction result was analyzed through qPCR and given in table 2 and graphical presentation in fig1 and fig 3. Samples checked through Nextractor NX-48 Genolution showed higher differences in cycle threshold $(\mathrm{Ct})$ values as dilution of pools increased. Samples R 1419 and R 1423 showed negative $(\geq 36)$ with the dilutions of $1: 6,1: 9$ and 1:10 respectively. It showed less sensitivity in extraction when result was compared with control values table 2 and fig.2. in case of Nextractor NX-48 Genolution results were not satisfactory towards sensitivity and efficiency of extraction in our study. In case of MagNA Pure 24 Roche and MDI Viral RNA Extraction Mini-prep Kit extraction showed high efficiency and sensitivity in approximately all samples. Kit based manual extraction results were better than Nextractor NX-48 Genolution.

\section{DISCUSSION \& CONCLUSION}

In this study, we found that the results of MagNa Pure 24 Roche and MDI Viral RNA Extraction Mini-prep Kit extraction are better as compared to Nextractor NX-48 Genolution. As regards the duration of the time of provided manual extraction is the shortest method while MagNa Pure 24 Roche took the longest time. Some modifications in the manual method could further shorten the duration. Results of Nextractor NX-48 Genolution gave higher $\mathrm{Ct}$ values than control. The results of the pools in 1: 5 however comparable with the other two methods.

As per interpretation of results pools of $(1: 5-1: 10)$ can be recommended for listing in the time of high load of samples. The purpose of this study is to introduce that the increased size of pooling samples protocol will be helpful to save time, labor and logistics along with the reducing cost per test which is important in this crisis time. This will also reduce the plastic biohazard waste generated due to large scale testing in this COVID crisis. Manual method involves less expenditure as compared to automated nucleic extraction machines and their costly consumables. One caution to prevent false negativity in pools is proper standardization of sample and chemical volume. Also the size of the pools 
depends largely on the load of positivity in the community.

\section{Financial Support}

None

\section{Conflict of Interest}

The authors declare that there is no conflict of interests regarding the Publication of this research article.

\section{Acknowledgement: None}

\section{Ethical Approval: Approved}

\section{REFERENCES}

1. Kumar D, Malviya R, Kumar Sharma P. Corona Virus: A Review of COVID-19. EJMO 2020; 4 (1):8-25.

2. Centers for Disease Control and Prevention (CDC). Update: Outbreak of severe acute respiratory syndrome--worldwide, 2003. MMWR Morb Mortal Wkly Rep. 2003; 52 (12) : 241-6.

3. World Health Organization. Coronavirus never before seen in humans is the cause of SARS- update 31. Geneva: The Organization; 2003.

4. World Health Organization. Summary of probable SARS cases with on sets of illness from 1 November 2002 to 31 July 2003. Available at http://www.who.int/csr/sars/country/table20 04_04_21/en/index.html. Accessed 14 feb 2020.

5. Peiris JS, Lai ST, Poon LL, Guan Y, Yam LY, Lim W, et al. Coronavirus as a possible cause of severe acute respiratory syndrome. Lancet.2003; 361:1319-25.

6. Mailles A, Blanckaert K, Chaud P, van der Werf S, Lina B, Caro V, et al. First cases of Middle East respiratory syndrome Coronavirus (MERS-CoV) infections in France, investigations and implications for the prevention of human-to-human transmission,Euro Surveill. 2013; 18: 20502.

7. Buchholz U, Muller MA, Nitsche A, Sanewski A, Wevering N, Bauer-Balci T, et al. Contact investigation of a case of human novel coronavirus infection treated in a German hospital, October- November 2012. Euro Surveill. 2013;18: 20406.
8. Saif LJ. Animal coronaviruses: what can they teach us about the severe acute respiratory syndrome? Rev Sci Tech. 2004;23: 643-60.

9. World Health Organization (2020) Novel Coronavirus (2019-nCoV) Situation Report $22 . \quad$ on-reports/20200211-sitrep-22ncov.pdf?sfvrsn=fb6d49b1_2. Accessed 17 May 2020

10. World Health Organization (2020) Novel Coronavirus (2019-nCoV) Situation Report 120. https://www.who.int/docs/defaultsource/coronaviruse/situationreports/20200519-covid-19-sitrep120.pdf?sfvrsn=515cabfb_2. Accessed 19 May 2020

11. Chu DKW, Pan Y, Cheng SMS, Hui KPY, Krishnan P, Liu Y, et al. Molecular Diagnosis of a Novel Coronavirus (2019$\mathrm{nCoV}$ ) Causing an Outbreak of Pneumonia. Clin Chem. 2020 Apr 1; 66 (4):549-555. doi: 10.1093/clinchem/ hvaa029.

12. Corman VM, Landt O, Kaiser M, Molenkamp R, Meijer A, Chu DKW, Bleicker T, Brunink S, et al. Detection of 2019 novel coronavirus (2019-nCoV) by real-time RTPCR. Euro Surveill. 2020 Jan 23; 25(3): 2000045 . doi: 10.2807/15607917.ES.2020.25.3.2000045.

13. Cheng MP, Papenburg J, Desjardins M, Kanjilal S, Quach C, Libman M, et al. Diagnostic Testing for Severe Acute Respiratory Syndrome-Related Coronavirus-2: A Narrative Review. Ann Intern Med. 2020 Apr 13: M20-1301. doi: 10.7326/M20-1301.

14. World Health Organization. Coronavirus Disease 2019 (COVID- 19). Situation Report -120. Updated June 10,2020. Accessed June 11,2020. https://www.who.int/docs/defaultsource/coronaviruse/situationreports/20200610-covid-19-sitrep-142.pdf? sfvrsn1/4180898cd_2.

15. Centers for Disease Control and Prevention. Interim Guidelines for Collecting, Handling and Testing Clinical Specimens from Persons for Coronavirus Disease 2019 (COVID-19). Updated July 8, 2020. Accessed April 16,2020. https://www.cdc.gov/cor onavirus/2019nCoV/lab/guidelines-clinicalspecimens.html

16. Fomsgaard AS, Rosenstierne MW. An alternative workflow for molecular detection of SARS-CoV-2 - escape from the 
NA extraction kit-shortage, Copenhagen, Denmark, March 2020. Euro Surveill 2020;25.

17. Yelin I, Aharony N, Shaer-Tamar E, Argoetti A, Messer E, Berenbaum D, et al. Evaluation of COVID-19 RT-qPCR test in multi-sample pools. Clin Infect Dis 2020.

18. Yan C, Cui J, Huang L, Du B, Chen L, Xue G, et al. Rapid and visual detection of 2019 novel coronavirus (SARS-CoV-2) by a reverse transcription loop-mediated isothermal amplification assay. Clin Microbiol Infect 2020;26(6):773e9. https://doi.org/10.1016/j.cmi.2020.04.001.

19. Ben-Assa N, Naddaf R, Gefen T, Capucha T, Hajjo H, Mandelbaum N, et al. SARSCoV-2 on-the-spot virus detection directly from patients. medRxiv 2020. https://doi.org/10.1101/2020.04.22.2007238 9. 04.22.20072389.

20. Lucia C, Federico P-B, Alejandra GC. An ultrasensitive, rapid, and portable coronavirus SARS-CoV-2 sequence detection method based on CRISPR-Cas12. bioRxiv 2020. 2020.2.29.971127.

21. Xiao S-Y, Wu Y, Liu H. Evolving status of the 2019 novel coronavirus infection: proposal of conventional serologic assays for disease diagnosis and infection monitoring. J Med Virol 2020; 92:464e7.

22. Barra GB, Santa Rita TH, Mesquita PG, Jacomo RH, Nery LFA. Analytical sensibility and specificity of two RT-qPCR protocols for SARS-CoV-2 detection performed in an automated workflow. medRxiv 2020. https://doi.org/ 10.1101/2020.03.07.20032326

23. Kalikiri MKR, Hasan MR, Mirza F, Xaba T, Tang P, Lorenz S. High-throughput extraction of SARS-CoV-2 RNA from nasopharyngeal swabs using solid-phase reverse immobilization beads. medRxiv 2020 . https://doi.org/10.1101/ 2020.04.08.20055731. 04.08.20055731.

How to cite this article: Kumar A, Dhull P, Manisha et.al. Sensitivity Comparison of different methods used for RNA extraction with increasing capacity for the detection of COVID19. International Journal of Research and Review. 2021; 8(7): 142-148. DOI: https://doi. org/10.52403/ijrr.20210719 